\title{
Experimental Model of Suction Head on Expansive Soil Subgrade with Concrete Wall Moisture Barrier
}

\author{
Maricar, M. Husni ${ }^{1}$, Samang, Lawalenna ${ }^{2}$, Pallu, Muh. Saleh ${ }^{3}$ dan Tjaronge, Wihardi ${ }^{4}$
}

\begin{abstract}
The losses incurred due soils ekspansivity primarily on lightweight structures are staggering. Erecting moisture barrier at the road side is a combination of providing a positive treatment and construction structures necessary to control water content change in the soil layer. This study aims to determine behavior of suction, moisture barrier effects on suction head reduction, and the laboratory experimental model of suction head profile. The test model was made to resemble half of the road width with a load of $30 \mathrm{kPa}$ on it, and install a concrete wall moisture barrier at road side with a depth variation of $20 \mathrm{~cm}, 35 \mathrm{~cm}$ and $50 \mathrm{~cm}$. Observation of time and water infiltration carried out on 8 observatories, also the amount of swelling through a dial that is placed above the concrete slab load. The results showed an increase in capillary water in front bulkhead for all variations of moisture barrier depth and water height reduction occurred in the rear bulkhead respectively $3.25 \%, 21.25 \%$ and $45 \%$ for the ratio of bulkhead height and expansive soil thickness $\mathrm{h} / \mathrm{H}=0.44, \mathrm{~h} / \mathrm{H}=0.78$ and $\mathrm{h} / \mathrm{H}$ $=1.11$. Also reduction of swelling respectively by $4.46 \%, 52.69 \%$ and $82.53 \%$ for each ratio $\mathrm{h} / \mathrm{H}$.
\end{abstract}

Keywords - expansive soils, moisture barrier, suction, suction head

\section{INTRODUCTION}

$\mathrm{E}^{\mathrm{x}}$ XPANSIVE soil can be defined as soils that has a special character in terms of swelling and shrinkage, primarily due to the presence of smectite clay minerals such as montmorillonite, illite, bentonite and the like which can absorb water from the surroundings in a relatively large percentage. Through a simple test in the laboratory, the expansive potential of a type of soil which can be characterized by the nature of plasticity. High plasticity inorganic clay which generally has a limit value of liquid (LL) above $50 \%$ and the plasticity index (PI) above $30 \%$ usually has the large capability swelling [11]. With the visualization in the field, the baseline characteristics of expansive soil are easily recognizable by the many cracks in the surface of the polygonal patterned ground are commonly encountered during the dry season.

Sometimes the construction of new roads to be built or the old road have already on above the expansive soil layers with a sufficiently deep thickness. The change of climate

Maricar, M. Husni ${ }^{1}$ is Student of Doctoral Programme in Civil Engineering Faculty, Hasanuddin University

Samang, Lawalenna ${ }^{2}$, was Professor in Civil Engineering Faculty, Hasanuddin University.

Pallu, Muh. Saleh ${ }^{3}$ was Professor in Civil Engineering Faculty, Hasanuddin University

Tjaronge, Wihardi ${ }^{4}$ was Professor in Civil Engineering Faculty, Hasanuddin University that lasts throughout the year and repetitive primarily in semiarid regions lead to a condition of this road structure is unstable due to the influence of fluctuations in water levels on the expansive soil layer. This condition will eventually have an impact on the declining function of the way during the life of service and will further contribute to the relatively high increase in road maintenance costs required..

Innovative thinking to address this challenge both as an alternative as well as the development of technologies that already exist and are often applied to the present needs to be appreciated. This development could be related to the effort of improvement the expansive soil material characteristics itself, concerned with providing positive impact treatment on the expansive soil layer, construction engineering structures necessary, or a combination of that several groups method.

Research topics presented here is a small part of the strategic issues to examine one of the alternative methods to address the adverse effects of expansive soil by taking an object on road construction. Alternative methods to be observed further that by installing a vertically concrete wall bulkhead as a moisture barrier to see the behavior of the water level in the expansive soil layer as road subgrade if the surrounding flooded. This study aims to determine the behavior of suction, moisture barrier effects on suction head reduction, and the experimental model of suction head profile with the erecting and testing of the models in the laboratory.

\section{THEORITICAL BACKGROUND}

\section{A. Geotechnical Aspect of Ekspansive Soils}

Reference [12] states that the soils classification system is a method that systematically categorizes soil materials into different groups and subgroups with respect to possibility of physical and engineering properties but without accompanied by a detailed description. Most soil classification system is based on the quantities of particle size distribution, the texture, the boundaries of consistency, moisture content, density, and organic ingredients. Categorization is almost no criteria at all to assess soils expansivity.

Expansive soil are generally classified as fine-grained soil that is where more than $50 \%$ the size of the particles passed from sieve No. 200, or less than $0.076 \mathrm{~mm}(2 \mathrm{~m} \mu)$.

Today has been a lot of research that aims to establish methods and criteria as the most appropriate indicator to identify and characterize the expansive soils both in the laboratory and in the field. The indicators are expected to be 
used as a general reference for a preliminary assessment or predict levels of soil expansivity. Among the criteria and indicators, there is a link between expansivity of soil with liquid limits as published by [2] and the [12[ as shown in Table 1.

TABLE I

PREDICTION OF SOIL EXPANSIVITY BASE ON LIQUID LIMIT

\begin{tabular}{ccc}
\hline \multirow{2}{*}{ Expansivity grade } & \multicolumn{2}{c}{ Liquid limit } \\
\cline { 2 - 3 } & Chen & IS 1498 \\
\hline \hline Low & $<30$ & $20-35$ \\
Fair & $30-40$ & $35-50$ \\
High & $40-60$ & $50-70$ \\
Very High & $>60$ & $70-90$ \\
\hline
\end{tabular}

Beside that, there are links between soil expansivity with plasticity index as proposed by Holtz and Gibbs (1956), Chen (1975), and Bureau of Indian Standards (1987) [12] as shown in Table 2.

TABLE II

PREDICTION OF SOIL EXPANSIVITY BASE ON PLASTICITY INDEX

\begin{tabular}{|c|c|c|c|}
\hline \multirow{2}{*}{$\begin{array}{l}\text { Expansivity } \\
\text { grade }\end{array}$} & \multicolumn{3}{|c|}{ Plasticity Index $(\%)$} \\
\hline & Holtz dan & Chen & IS \\
\hline Low & $<20$ & $0-15$ & $<12$ \\
\hline Fair & $12-34$ & $10-35$ & $12-23$ \\
\hline High & $23-45$ & $20-55$ & $23-32$ \\
\hline Very High & $>32$ & $>35$ & $>32$ \\
\hline
\end{tabular}

The development of further research on the characteristics of expansive soil found other parameters so that some one correlate soil expansivity with these parameters, ie kaloid content, the shrinkage limit, the shrinkage index, and free swell index (FSI), as shown in Table 3.

PREDICTION OF SOIL EXPANSIVITY BASE ON OTHER PARAMETERS

\begin{tabular}{|c|c|c|c|c|c|c|}
\hline \multirow[t]{2}{*}{$\begin{array}{l}\text { Expansivity } \\
\text { grade }\end{array}$} & \multirow{2}{*}{$\begin{array}{c}\text { Koloid } \\
\text { content } \\
(\%)\end{array}$} & \multirow{2}{*}{$\begin{array}{c}\text { Shrinkage } \\
\text { limit } \\
(\%)\end{array}$} & \multirow{2}{*}{$\begin{array}{c}\text { Shrinkage } \\
\text { index } \\
(\%)\end{array}$} & \multirow[t]{2}{*}{$\begin{array}{l}\text { FSI } \\
(\%)\end{array}$} & \multicolumn{2}{|c|}{$\begin{array}{l}\% \text { of swelling in } \\
\text { oedometer, }\end{array}$} \\
\hline & & & & & $\begin{array}{l}\text { Holtz \& } \\
\text { Gibbs }\end{array}$ & $\begin{array}{l}\text { Seed, at } \\
\text { al. }\end{array}$ \\
\hline Low & $<17$ & $>13$ & $<15$ & $<50$ & $<10$ & $0-1,5$ \\
\hline Fair & $12-27$ & $8-18$ & $15-30$ & $50-100$ & $10-20$ & $1,5-5$ \\
\hline High & $18-37$ & $6-12$ & $30-60$ & $100-200$ & $20-30$ & $5-25$ \\
\hline Very High & $>27$ & $<10$ & $>60$ & $>200$ & $>30$ & $>25$ \\
\hline
\end{tabular}

\section{B. Basic Concept of Suction Head in Expansive Soils}

The fundamental theory concept of suction in unsaturated soil was developed in the early era of 1900s by Buckingham, 1907; Gardner and Widtsoe, 1921; Richard, 1928; Schofield, 1935; Edlefsen and Anderson, 1943; Childs and Collis-George, 1948; Bolt and Miller, 1958; Corey and Kemper, 1961; and Corey et al, 1967 [6]. This theory is generally constructed of a physical relationship in the system soil-water-plant. The role of suction in geotechnical problems newly recognized around 1950, and in 1965 a panel symposium soil mechanics themed "Moisture Equilibradan Moisture Change in Soils" establishes the definition of quantitative suction and components on the soils from the context of thermodynamics, which then this concept is accepted in geotechnical engineering.

Soil consists of solid particles and void. there are two void components for unsaturated soil, namely air and water. In the context of thermodynamics the total amount of suction $(\psi)$ can be quantified according to Kelvin equation as follows:

$$
\psi=-\frac{R T}{v_{w 0} w_{v}} \ln \left(\frac{\overline{\mathrm{U}}_{v}}{\overline{\mathrm{U}}_{v 0}}\right)
$$

where:

$$
\begin{aligned}
\psi= & \text { total suction }(\mathrm{kPa}) \\
\mathrm{R}= & \text { molar gas constant }(8,31432 \text { joule } / \mathrm{mol} \mathrm{K}) \\
\mathrm{T}= & \text { absolute temperature }(\mathrm{K}) \\
\mathrm{V}_{\mathrm{w} 0}= & \text { specific volume of water }\left(\mathrm{m}^{3}\right) \\
\mathrm{w}_{\mathrm{v}}= & \text { molecular mass of water vapor }(18,016 \mathrm{~kg} / \mathrm{kmol}) \\
\overline{\mathrm{v}}_{\mathrm{v}}= & \text { pore water vapor partial pressure }(\mathrm{kPa}) \\
\overline{\mathrm{v}}_{\mathrm{v} 0}= & \text { saturated water vapor pressure on a flat surface } \\
& (\mathrm{kPa})
\end{aligned}
$$

At temperatures of $20^{\circ} \mathrm{C}$, equation (8) can be rewritten in the simple form as:

$$
\psi=-135,022 \ln \left(\frac{\overline{\mathrm{U}}_{V}}{\overline{\mathrm{U}}_{V 0}}\right)
$$

The component of $\mathrm{U}_{\mathrm{V}} / \overline{\mathrm{U}}_{\mathrm{v} 0}$ referred to as relative humidity. A typical graph of the relationship between the total suction and relative humidity for three different temperature conditions are: 


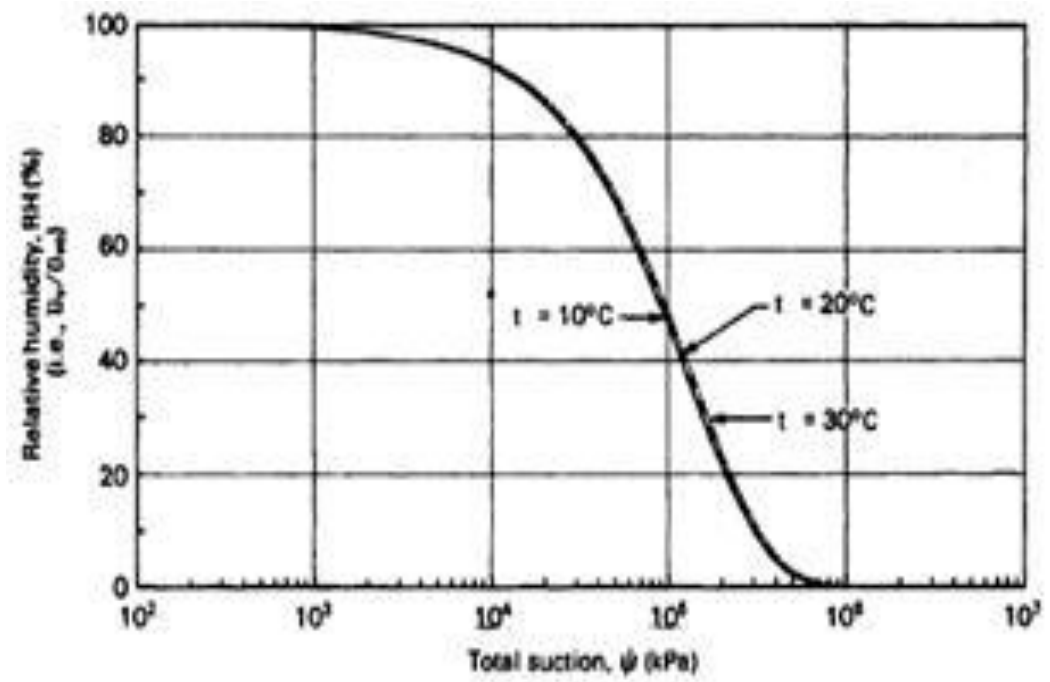

Fig. 1 Relationship between relative humidity with total suction

\section{Component of Suction}

Meaning of soil suction in relation with the relative humidity as Equation 2 above are referred to "total suction". Total suction consists of two components, namely the matric suction and osmotic suction. Meaning of each suction components is [6]:

- Component Matric suction or capillary; suction equivalent to the measurement of partial pressure of water vapor in equilibrium with the water in the soil, relative to partial pressure of water vapor in equilibrium with a solution together that is mixed with water in the soil.

- Components of osmotic suction; suction equivalent to the measurement of partial pressure of water vapor in equilibrium with a particular solution that is mixed with water in the soil, relative to partial pressure of water vapor in equilibrium with pure water.

- Total suction or free energy of water in the soil; suction equivalent to the measurement of partial pressure of water vapor in equilibrium with a solution similar in composition to the water in the soil, relative to partial pressure of water vapor in balance with pure free water.

From the definition above shows that total suction is a combination of free energy of water in the soil, being matric and osmotic suction is a component of the free energy. In equation form, the relationship can be written as:

$$
\psi=\left(U_{a}-U_{w}\right)+\pi
$$

where:

$$
\begin{aligned}
\psi & =\text { total suction } \\
(\mathrm{Ua}-\mathrm{Uw}) & =\text { matric suction } \\
\mathrm{Ua} & =\text { air pressure inside the pore } \\
\mathrm{Uw} & =\text { pore water pressure in the ground } \\
\pi & =\text { osmotic suction }
\end{aligned}
$$

\section{Capillarity}

Reference [1] writes in his book that the analogy commonly used to describe the relationship soil-air system is that the grained soil particles are separated by water. In the air-water relationship, a meniscus is formed in the soil body adjacent in a sense similar to the incidence of water in a capillary tube. Therefore, it is understood that this system can be associated as a model of capillary. The balance of the air-water relationship in the capillary tube in Fig. 2, shows that the force pressed down of air should be equal to the upward force of the water. Shape of the curve on the interface as the tube wall, occurs because of the surface attractive force of two adjacent media. The upward force of surface tension of water will push up the water column from the surface of the water outside the tubes. Therefore:

$$
u_{a} \pi r^{2}+u_{w} \pi r^{2}+2 \pi r T_{s} \cos \alpha
$$

where:

$\mathrm{r} \quad=$ radius of the capillary tube

$\mathrm{Ts}=$ surface tension of water

$\alpha=$ contact angle between the water and the tube wall

If the meniscus in a perfect spherical then $\alpha$ will be $0^{\circ}$ and the balance would be reduced to:

$$
u_{a}-u_{w}=\frac{2 T_{s}}{r}
$$

\section{Capillary Rise}

The balance of the vertical forces of capillary water in the tube as shown in Error! Reference source not found., the resultant vertical force of surface tension that is $(2 \pi \mathrm{r}$ Ts $\cos$ $\alpha$ ) is responsible for lifting the weight of the water column in the tube which has a height $h_{c}$ of $(\pi r 2 h c \rho w g)$. Balance becomes:

$$
2 \pi r T_{s} \cos \alpha=\pi r^{2} h_{c} \rho_{w} g
$$

where: $\quad \mathrm{h}_{\mathrm{c}}=$ capillary height

$\rho_{\mathrm{w}}=$ water density

$\mathrm{g}=$ gravity acceleration

Equation (6) can be rearranged to get the maximum water level in the capillary tube into:

$$
h_{c}=\frac{2 T_{s} \cos \alpha}{\rho_{w} g r}
$$

The contact angle between the surface of the capillary tube and pure water is zero. When $\alpha=0$, then Rs curvature radius equal to the radius of the capillary tube, r. Therefore, the higher capillary for pure water in a clean glass tube are:

$$
h_{c}=\frac{2 T_{s}}{\rho_{w} g r}
$$




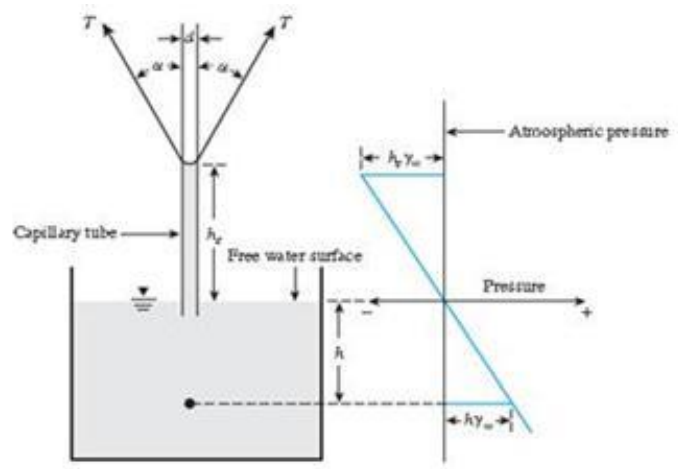

Fig. 2 The physical model and the phenomenon of capillarity

\section{Conceptual Framework}

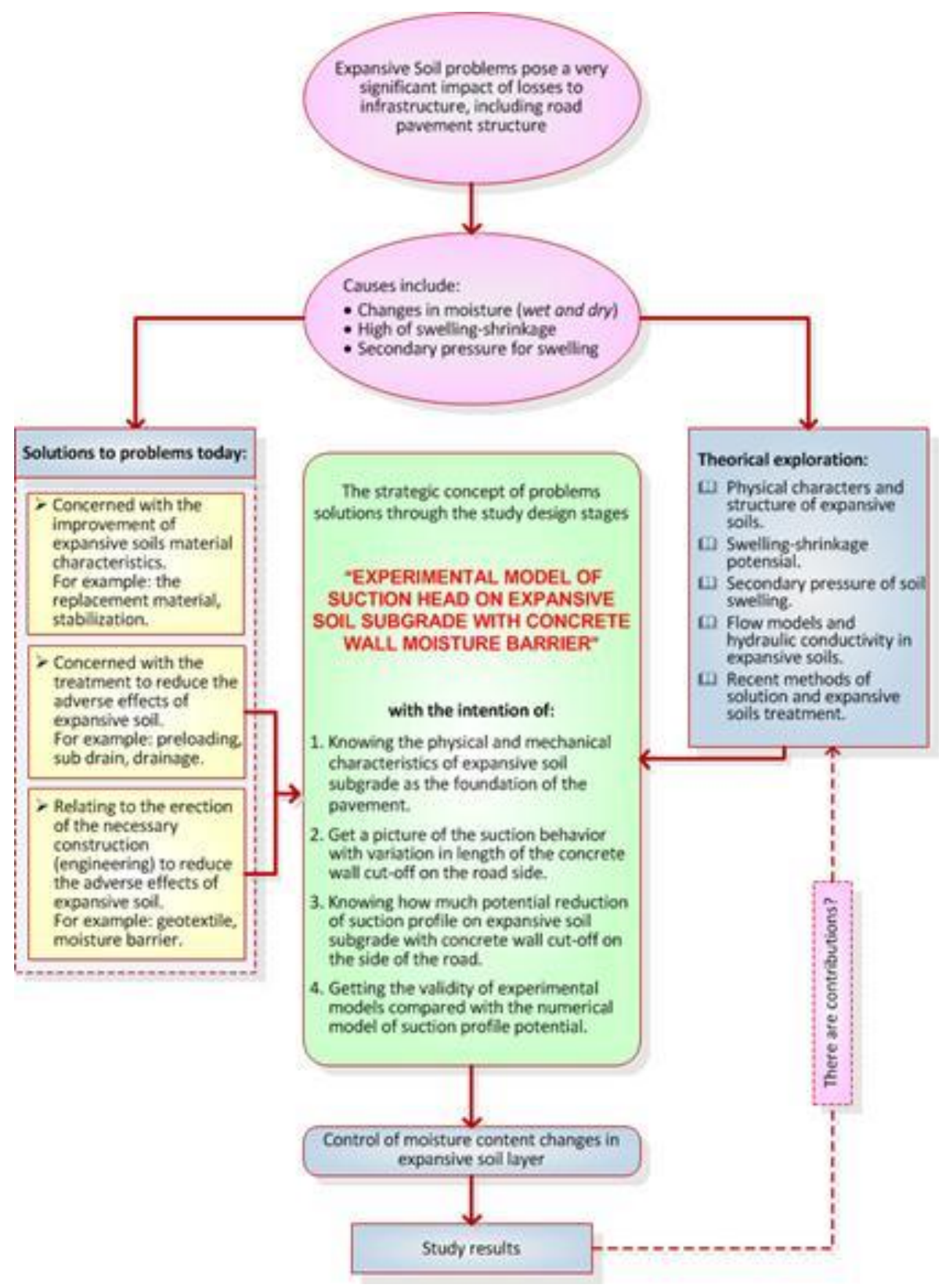

Fig. 3 Conceptual Framework of Study 


\section{Methodology}

Experiment conducted in Soil Mechanics Laboratory of Engineering Faculty, Hasanuddin University. Source of expansive soils sample taken from Siwa village, District of Pitumpanua, Wajo Regency, South Sulawesi Province, precisely located at 253,070 km from Makassar.

Steps of research design conducted can be described as follow:

1. Conduct a survey, literature and reference journals review and then to identify and determine the location of expansive soil material sampling.

2. Perform initial testing to identify the physical and mechanical character of the expansive soil samples material.
3. Creation of a model tested in the laboratory as shown in Fig. 4 by varying the depth of the moisture barrier concrete wall. Variation of moisture barrier depth are $20 \mathrm{~cm}, 35 \mathrm{~cm}$ and $50 \mathrm{~cm}$ from model tested surface, with the rasio of moisture barrier depth (h) and expansive soil layer thickness $(\mathrm{H}=45 \mathrm{~cm})$ as $\mathrm{h} / \mathrm{H}=0,44, \mathrm{~h} / \mathrm{H}=0,78$, and $\mathrm{h} / \mathrm{H}=1,11$.

4. To observe and testing water infiltration and suction process into the expansive soil to gain relationship between infiltration time, the depth ratio of the bulkhead and expansive soil layer thickness $(\mathrm{h} / \mathrm{H})$, and the water level.

5. Perform analysis of the test results and numerical validation of suction head on experimental data.

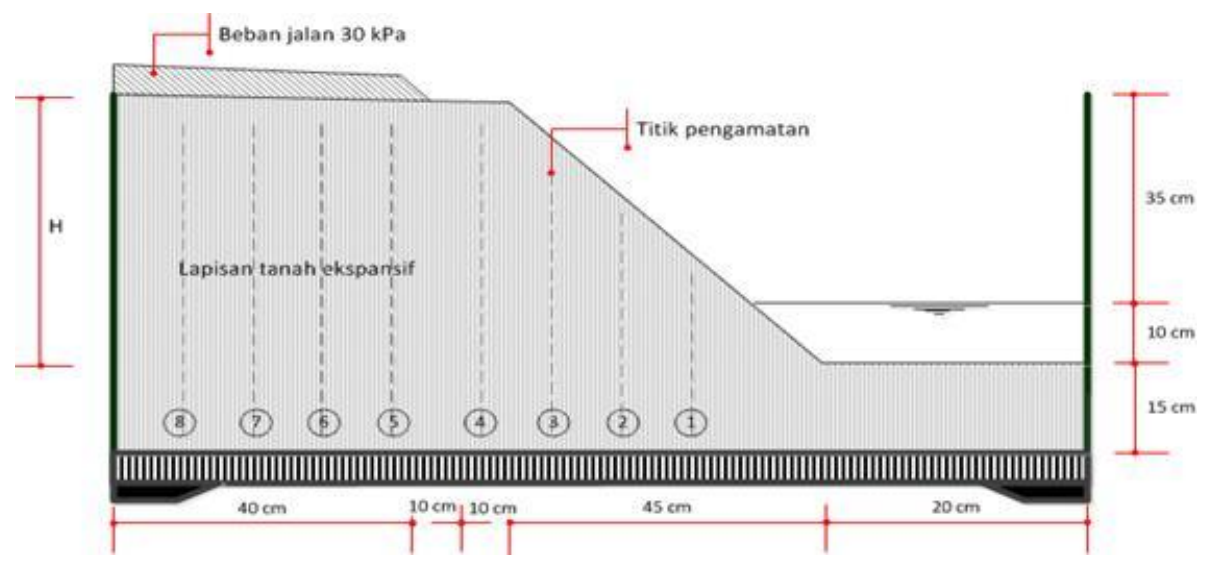

(a). without moisture barrier

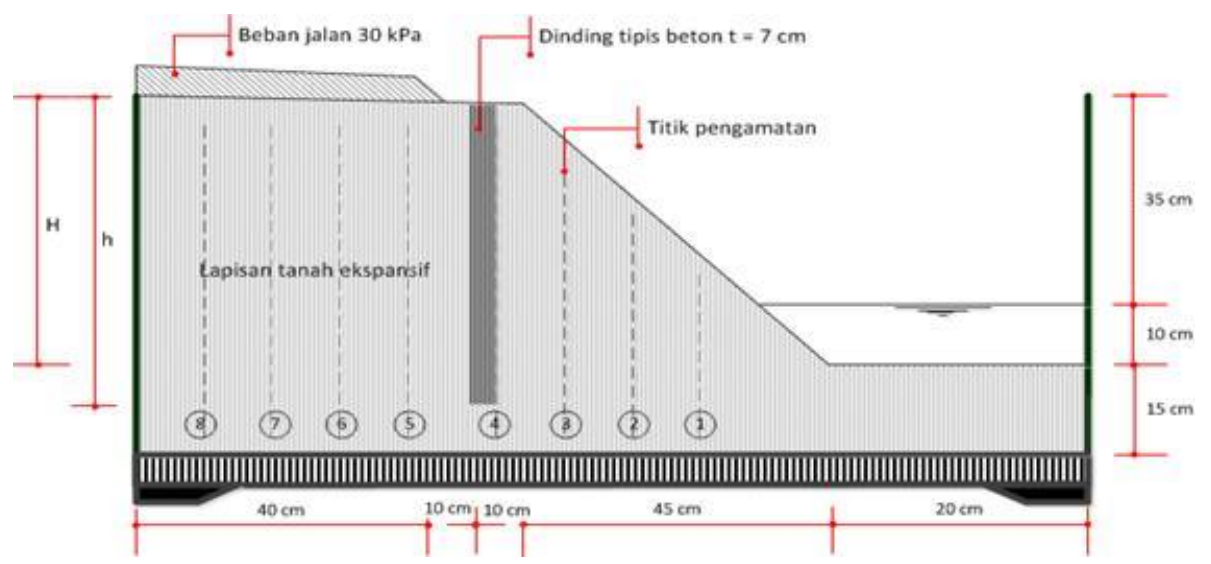

(b) With variation of ratio moisture barrier height

Fig. 4 Apparatus (testing model) which build in laboratory

\section{RESUlt AND DISCUSSION}

\section{A. Test Results of Soil Index Properties}

Results of initial testing conducted at the Laboratory of Soil Mechanics in Engineering Faculty of Hasanuddin University,
Campus Gowa, to get an overview of the properties of soil index, as shown in Error! Reference source not found. in this paper: 
TABLE IV

TEST RESULT OF SOIL INDEX PROPERTES

\begin{tabular}{|c|c|c|}
\hline Index Properties & $\begin{array}{l}\text { Number of } \\
\text { Test }\end{array}$ & Test Result \\
\hline \multicolumn{3}{|l|}{ a. Grain size analysis ${ }^{*}$ ) } \\
\hline - Gravel fraction & 3 & $0,18 \%$ \\
\hline - Sand fraction & 3 & $29,78 \%$ \\
\hline - Silt-clay fraction & 3 & $70,04 \%$ \\
\hline \multicolumn{3}{|l|}{ b. Consistency and Activity } \\
\hline - Liquid limit (LL) & 15 & $75,41 \%$ \\
\hline - Plastic limit (PL) & 15 & $43,95 \%$ \\
\hline - Plasticity index (PI) & 15 & $31,46 \%$ \\
\hline - Shrinkage limit (SL) & 3 & $16,56 \%$ \\
\hline - Activity (A) & 3 & 1,93 \\
\hline c. Specific gravity (Gs) & 3 & 2,542 \\
\hline d. Maximum dry density $\left(\gamma_{d}\right)$ & 1 & $1,288 \mathrm{gr} / \mathrm{cm}^{3}$ \\
\hline e. Optimum moisture content ( $\left.\mathrm{w}_{\mathrm{ag}}\right)$ & 1 & $32,40 \%$ \\
\hline f. Hydraulic conductivity & 3 & $0,001711 \mathrm{~cm} /$ second \\
\hline g. Degree of expansivity ${ }^{*}$ ) & 3 & High - Very high \\
\hline $\begin{array}{l}\text { h. Soil classitication } \\
\text { - USCS }\end{array}$ & & $\mathrm{MH}$ \\
\hline - AASHTO & & $A-7-5(25)$ \\
\hline
\end{tabular}

*) base on USCS soil clas sification system

8*) base on classification by Chen, Holtz and Gibbs

Soaking CBR tests was also carried out in the laboratory to determine the mechanical properties of the soil, concerning the bearing capacity and also swelling characteristic of the soil samples. Tests have been done 3 times to obtain an average value CBR amounted to $0.479 \%$ and the average value of swelling of $4.69 \%$.

\section{B. Identification of Clay Minerals by X-Ray Diffraction}

Sensing of the micro components or minerals contained in the fine-grained soil can be identified using X-Ray Diffractometer (XRD Method). The test results of X-ray diffraction transform each specimen will generate a graph illustrating the relationship between the magnitude of the intensity (counts) with the amount of 2 times the angle of

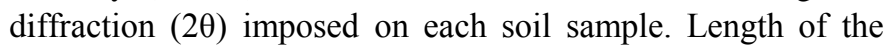

electromagnetic wave emitted by the X-ray and its order equal to the distance of atoms plane in the crystal ranged between 0.5 to 2.5 Armstrong, therefore X-ray capable to analyze crystal structure and identify crystalline mineral of soil [13]. From the diffraction chart readings can be identified minerals in the soil, either clay mineral and non-clay minerals.

The test results of X-Ray Diffraction that was done 2 times to the soil samples taken in the form of the relationship

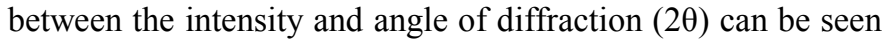
in Fig. 5. From that graph can be identified both the content and the proportion of clay minerals and non clay minerals in the 2 soil samples tested respectively as shown in TABLE and TABLE as follow.

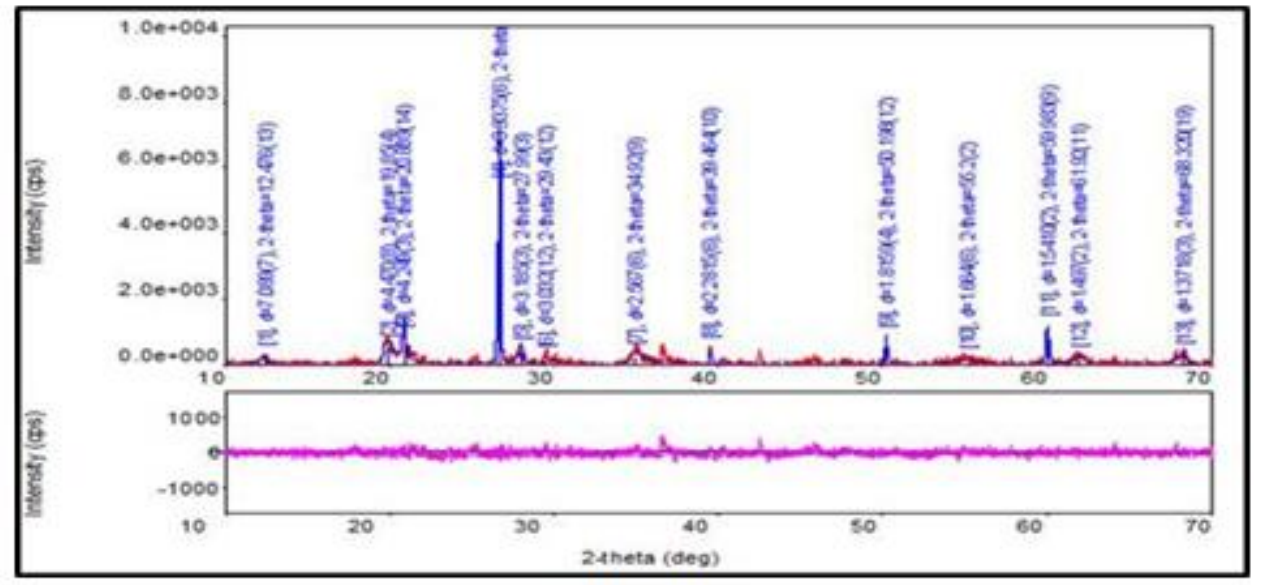

(a) Sample 1 


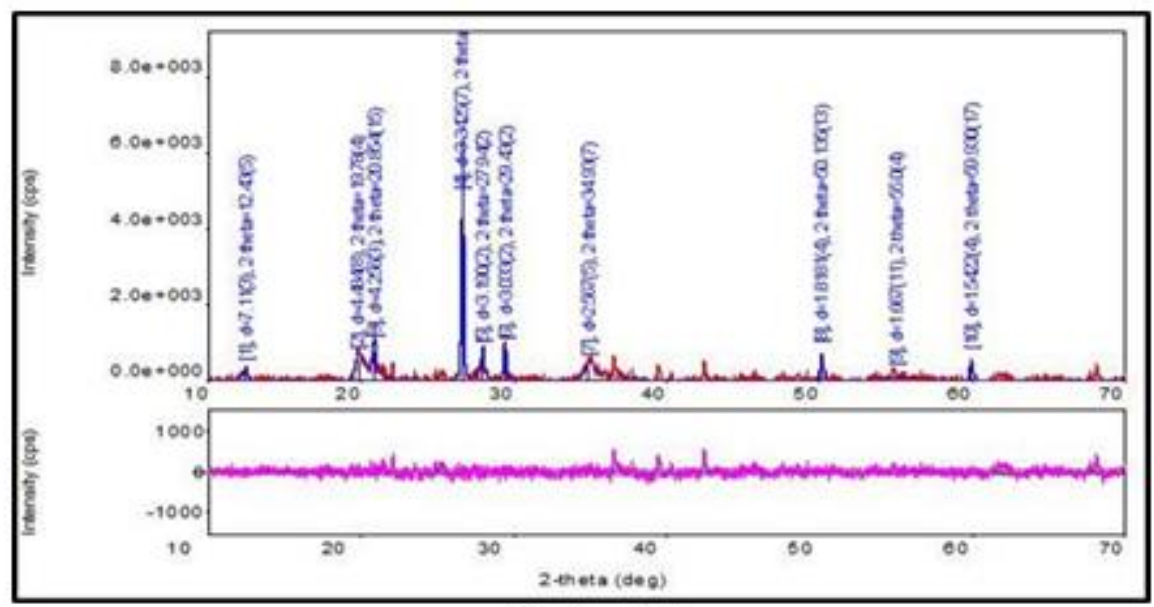

(b) Sample 2

Fig. 5 Graph of X-Ray Diffraction test result

TABLE V

Clay Minerals and Non Clay Minerals Content (SoIl Sample 1)

\begin{tabular}{lll}
\hline \multicolumn{1}{c}{ Mineral content } & \multicolumn{1}{c}{ Chemistry formula } & \multicolumn{1}{c}{ Content $(\%)$} \\
\hline \hline Kaolinite 1A & $\mathrm{Al}_{2} \mathrm{Si}_{2} \mathrm{O}_{5}(\mathrm{OH})_{4}$ & $4(2)$ \\
Illite - montmorillonite (NR) & $\mathrm{KAl}_{4}(\mathrm{Si}, \mathrm{AL})_{8} \mathrm{O}_{10}(\mathrm{OH})_{4} .4$ & $87(40)$ \\
Quartz, syn & $\mathrm{SiO}_{2}$ & $5(3)$ \\
Magnetite, syn & $\mathrm{Fe}_{3} \mathrm{O}_{4}$ & $1,1(6)$ \\
Rutile, syn & $\mathrm{TiO}_{2}$ & $2,0(6)$ \\
\hline
\end{tabular}

TABLE VI

Clay Minerals and Non Clay Minerals Content (SoIl SAMPLe 2)

\begin{tabular}{l|l|c}
\hline \multicolumn{1}{c|}{ Mineral content } & \multicolumn{1}{c|}{ Chemistry formula } & Content $(\%)$ \\
\hline \hline Kaolinite 1A & $\mathrm{Al}_{2} \mathrm{Si}_{2} \mathrm{O}_{5}(\mathrm{OH})_{4}$ & $4,6(17)$ \\
Illite - montmorillonite (NR) & $\mathrm{KAl}_{4}(\mathrm{Si}, \mathrm{AL})_{8} \mathrm{O}_{10}(\mathrm{OH})_{4} \cdot 4$ & $82(25)$ \\
Iron diiron (III) oxide, Magnetite & $\mathrm{Fe}_{3} \mathrm{O}_{4}$ & $8,5(19)$ \\
Rutile, syn & $\mathrm{TiO}_{2}$ & $1,8(6)$ \\
Quartz, syn & $\mathrm{SiO}_{2}$ & $0,3(9)$ \\
Corundum, syn & $\mathrm{Al}_{2} \mathrm{O}_{3}$ & $2,5(4)$ \\
\hline
\end{tabular}

From the results of the index properties testing in the laboratory and X-Ray Diffractometer output on expansive soil samples shown there is a match, namely:

1. The proportion of silt (particle size of $2 \mu-75 \mu$ ) were obtained from analysis hydrometer at $53.77 \%$, according to the USCS soil classification system that classifies soil sample as MH (high plasticity of inorganil silt)

2. The mineral content illite - montmorillonite as the predominant mineral in soil samples according to XRD results ranging from $82 \%-87 \%$ corresponds to the value of the activity (A) in the index properties of soil testing of 1.93. Based on the criteria in Table 4.1 in the textbook "Principles of Geotechnical Engineering", 7th edition,
2010 [3], value of $\mathrm{A}=1,93$ containing mineral montmorillonite and expansive.

\section{Suction Behavior with Depth Variation of Concrete Wall Moisture Barrier}

Tests on the physical model of expansive soil according Figure 4 above are designed with laboratory scale in a container box length $\mathrm{x}$ width $\mathrm{x}$ height of each $135 \mathrm{~cm} \times 50 \mathrm{~cm}$ x $60 \mathrm{~cm}$, conducted on four conditions variation depth of concrete wall moisture barrier, namely; a) conditions without using a concrete wall moisture barrier at all; b) conditions of use of the concrete wall bulkhead (h) as deep as $20 \mathrm{~cm}$ from the soil surface with a ratio of the expansive soil depth $(\mathrm{H}=45 \mathrm{~cm})$ range of $\mathrm{h} / \mathrm{H}=0.44 ; \mathrm{c}$ ) conditions of use concrete walls bulkhead as deep as $35 \mathrm{~cm}$ with a ratio $\mathrm{h} / \mathrm{H}=0.78$; and d) 
conditions of use concrete walls bulkhead $50 \mathrm{~cm}$ deep with a ratio $\mathrm{h} / \mathrm{H}=1.1$. Determination of using the depth of thin wall concrete $(\mathrm{h})$ of $20 \mathrm{~cm}, 35 \mathrm{~cm}$ and $50 \mathrm{~cm}$ is made based on consideration of the concrete wall bulkhead elevation essentially above the water level freely stagnant in the embankments, conditions concrete wall bulkhead elevation is essentially exactly the same with free water level inundation, and the condition of the concrete wall bulkhead elevation is essentially located at a depth below the water level in soil slope made. Observations and measurements were carried out
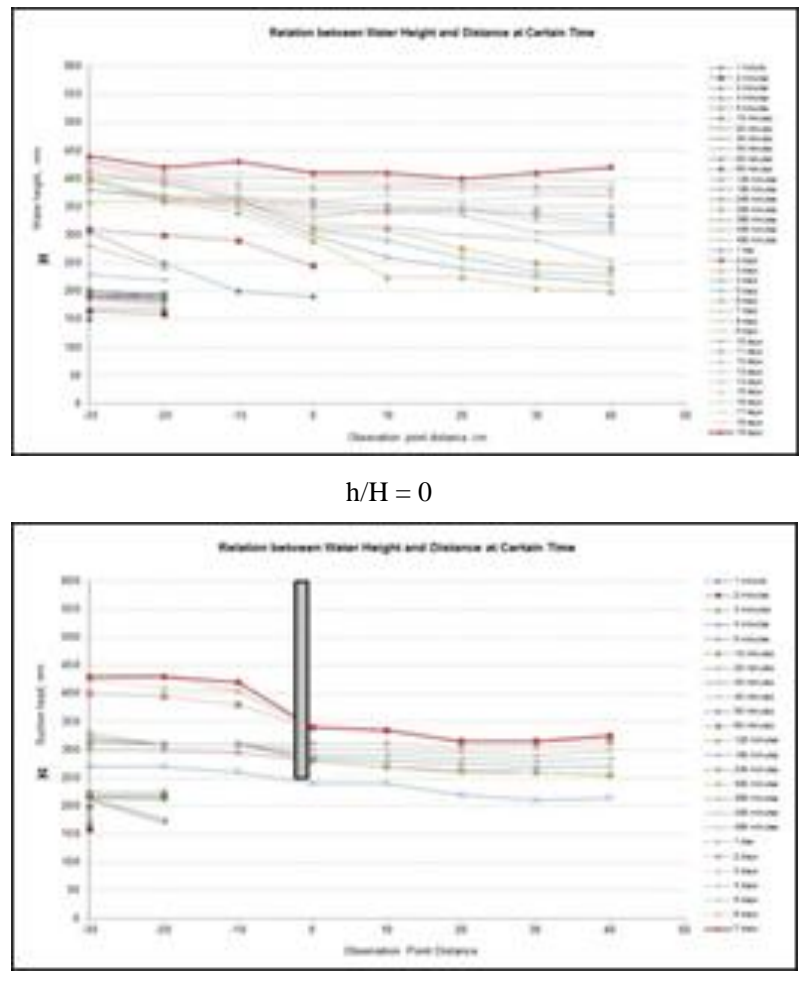

$\mathrm{h} / \mathrm{H}=0,78$ on test models for each of these conditions takes on average for 20 calendar days continuously.

1. The rate of water infiltration into the expansive soil layer

Observations and measurements of water infiltration process into the expansive soil layer both horizontally based on distance observation points, and the vertical direction by measuring the height of the achievements of water at each point of observation is presented in a graphic form that can be seen in FIG. 6.

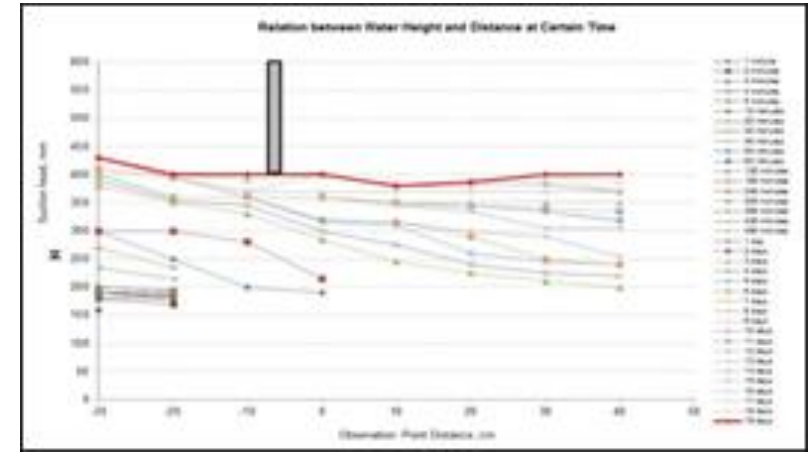

(b) $\mathrm{h} / \mathrm{H}=0,44$

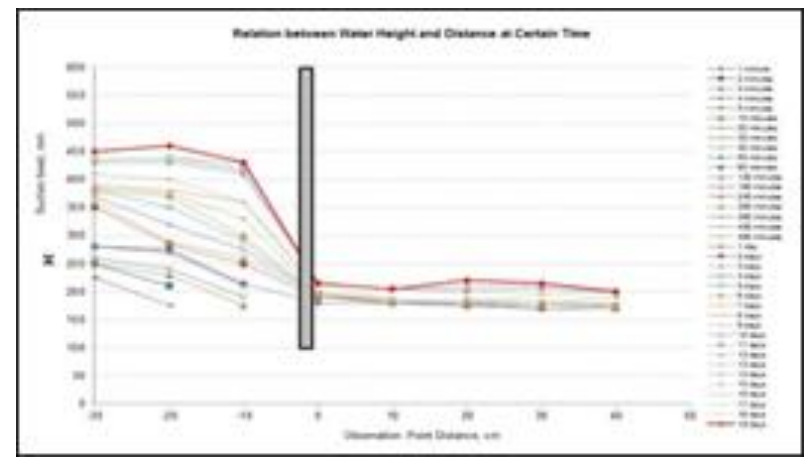

$\mathrm{h} / \mathrm{H}=1,11$

Fig. 6 Infiltration rate in expansif soil with variation of moisture barrier depth

For conditions without moisture barrier concrete walls, water diffusion in the horizontal direction into expansive soil layer observed from the water traveling initially relatively rapid about $0.08 \mathrm{~cm} / \mathrm{sec}$, and then slowed to around 0,0003 $\mathrm{cm} / \mathrm{sec}$ after the water content in the soil layer increased. Similarly, for conditions with ratio $\mathrm{h} / \mathrm{H}=0.44, \mathrm{~h} / \mathrm{H}=1.78$ and $\mathrm{h} / \mathrm{H}=1.11$ which have range of horizontal water diffusion from 0005 to $0.08 \mathrm{~cm} / \mathrm{sec}, 0.007$ to $0.008 \mathrm{~cm} / \mathrm{sec}$, and from

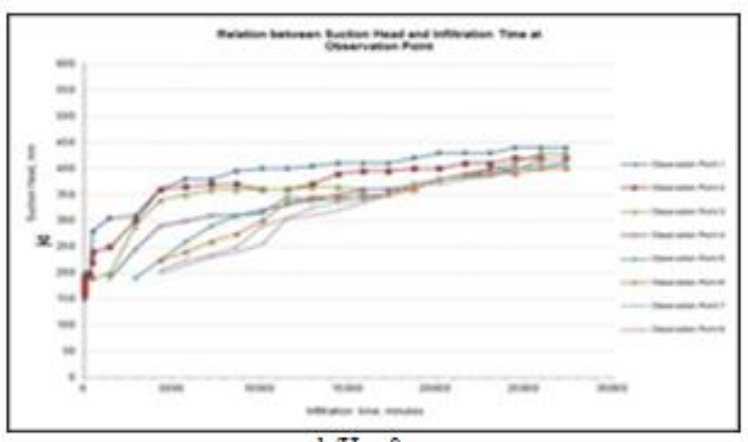

$\mathrm{h} / \mathrm{H}=0$
0.0009 to $0.005 \mathrm{~cm} / \mathrm{sec}$ respectively. It seems that the greater the ratio of the concrete wall bulkhead depth, or deeper concrete wall bulkhead would affect the rate of water diffusion decrease horizontally in the expansive soil layer.

The same thing happened on the diffusion of water in the soil layer of expansive to the vertical direction, initially spread rapidly and will eventually slow to a stop at a certain elevation as shown in Error! Reference source not found..

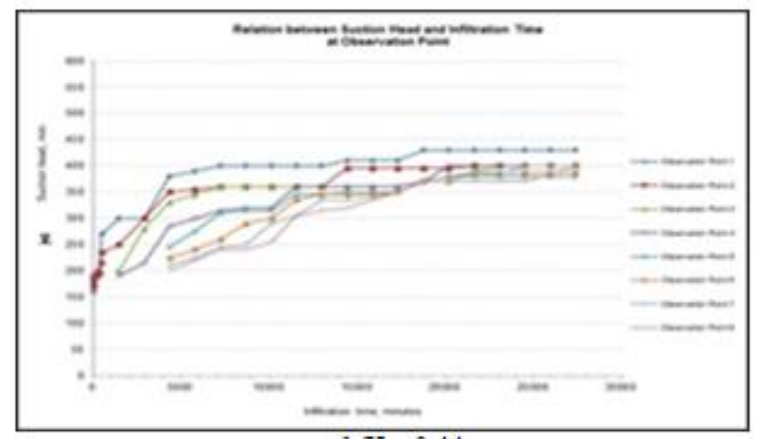

$\mathrm{h} / \mathrm{H}=0,44$ 


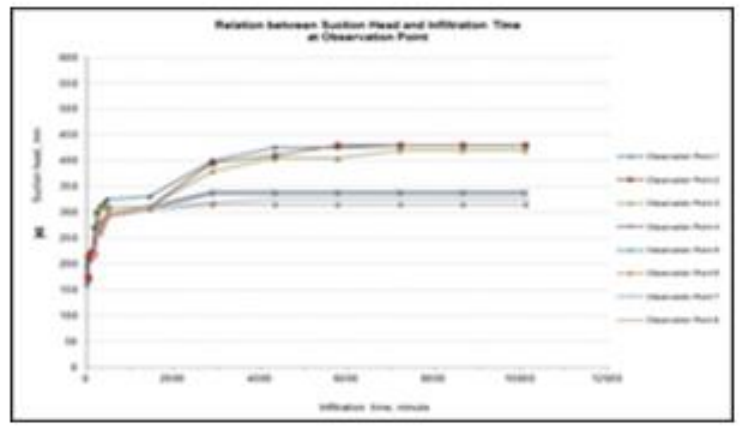

$\mathrm{h} / \mathrm{H}=0,78$

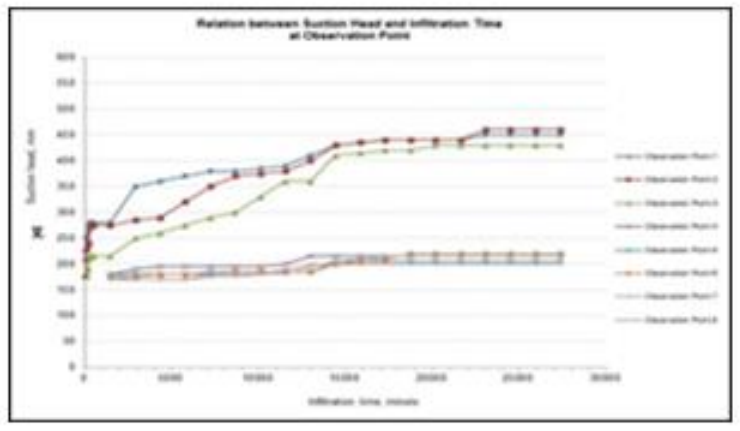

$\mathrm{h} / \mathrm{H}=1,11$

Fig. 7 Suction head rate at each of observatio point

Through measurements when testing the model obtained range rate of vertical direction water diffusion for each condition of the concrete wall bulkhead depth ratio in a row ranges from 0 to $0.025 \mathrm{~cm} / \mathrm{sec}$ for without the concrete walls bulkhead, from 0 to $0.033 \mathrm{~cm} / \mathrm{sec}$ for the ratio of $\mathrm{h} / \mathrm{H}=0.44,0$ to $0.017 \mathrm{~cm} / \mathrm{sec}$ for ratio $\mathrm{h} / \mathrm{H}=0.78$, and 0 to 0.004 on ratio $\mathrm{h} / \mathrm{H}=1.11$. Up here, there are at least two things that can be summed up in the context of the rate water diffusion into the expansive soil layer namely; 1) the higher the ratio of the depth of concrete wall bulkhead then the water slowly diffuse (spread) to the expansive soil layer; and 2) the rate of vertical direction water diffusion relatively faster than the horizontal direction water diffusion, especially in the early minutes of testing underway.

\section{Suction Behavior in the Expansive Soil Layers}

Error! Reference source not found. presents a comparison of negative pore water pressure profile at a certain depth of the expansive soil layer for each variation of the concrete wall bulkhead depth ratio. Seen from the graph, the decline in the extreme suction profile occurred at a depth of $50-40 \mathrm{~cm}$ to depth ratio $\mathrm{h} / \mathrm{H}=0.44$ and $\mathrm{h} / \mathrm{H}=0.78$. Phenomenon occurred due shallower depth of bulkhead causing water infiltration and capillarity can reach higher levels, being near the surface occurs due to evaporation during testing the model was left exposed. So the value of suction at a depth of $40 \mathrm{~cm}$ relative to getting down and at surface is getting up.Diffrent with depth of ratio $\mathrm{h} / \mathrm{H}=1.1$, due to the relative bulkhead deeper so water infiltration into the soil layer behind the bulkhead is somewhat hampered, causing no change suction in great value.

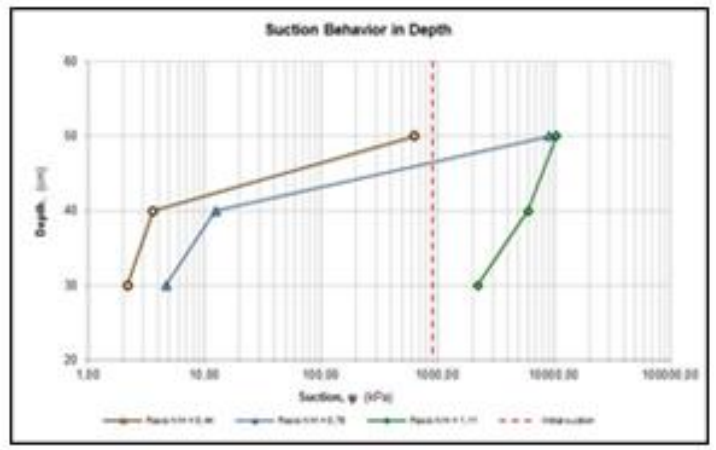

Fig. 8 Suction behavior in expansive soil layers

\section{D.Potential Reduction of Suction Head Profile due} Concrete Wall Moisture Barrier

As would be expected that the concrete wall bulkhead that serves as a moisture barrier, mounted on the side of the achievement test models will reduce water absorption and capillary height (suction head) expansive soil layer on the rear bulkhead mounted. The deeper moisture barrier or the greater ratio of $\mathrm{h} / \mathrm{H}$ attached then the lower the elevation of the water capillary achieved. This is because more and more in moisture barrier installed in expansive soil layer will cause the trajectory of the water conductivity path will be getting longer.

If the condition without concrete wall moisture barrier as a benchmark position then the magnitude of the suction head reduction of ratio $\mathrm{h} / \mathrm{H}=0.44, \mathrm{~h} / \mathrm{H}=0.78$ and $\mathrm{h} / \mathrm{H}=1.11$ respectively are 3,25\%,21.25\% and 45\%, according to FIG. 10.

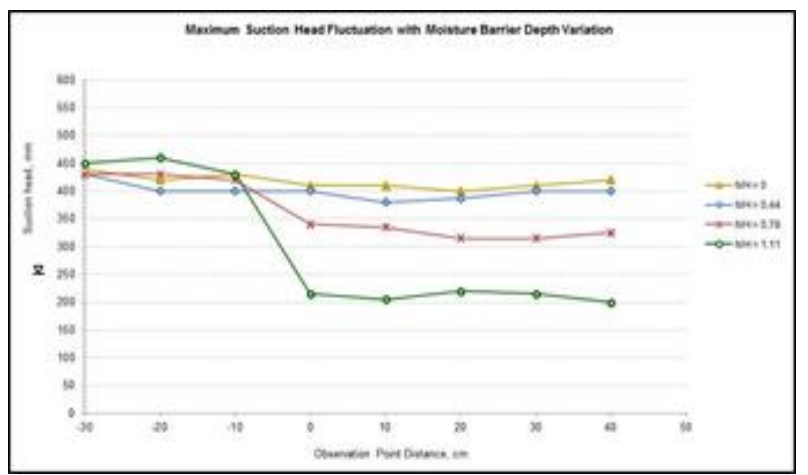

Fig. 9 Suction head reduction with variation of moisture barrier depth

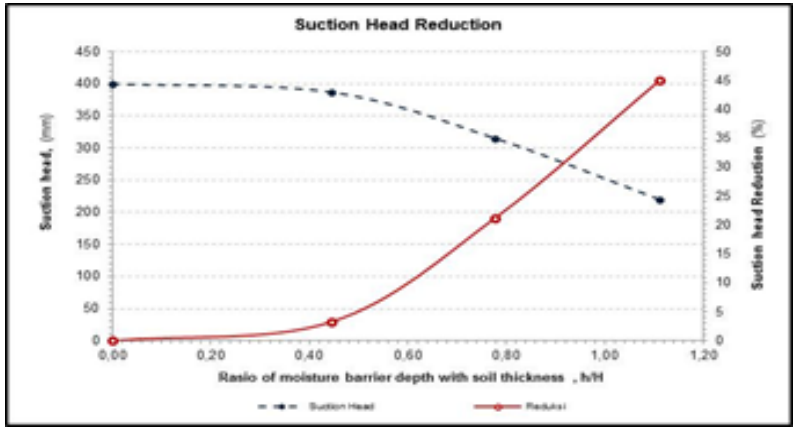

Fig. 10 Trend of suction head reduction with variation of moisture barrier depth ratio 


\section{V.CONCLUSIONS}

Some conclusions obtained from this study are:

1. There is a match between the test results of expansive soil index properties from laboratory through micro-structure testing X-Ray Diffraction.

2. The greater the ratio of the moisture barrier depth, the smaller the change in suction behavior of expansive soil layer.

3. The greater the ratio of the moisture barrier depth, the greater the suctio head reduction.

4. Necessary numerical validation to test the amount of suction head obtained from model tested in the laboratory results.

\section{REFERENCES}

[1] Charles, W.W.Ng., dan Bruce Menzies, 2007, Advanced Unsaturated Soil Mechanics and Engineering, 1st Published, Taylor \& Francis Group, New York, USA.

[2] Chen, F.H., 1975, Foundations on Expansive Soils, Elsevier Scientific Publishing Company, Amsterdam.

[3] Das, Braja M., 2010, Principles of Geotechnical Engineering, 7th Edition, Cengage Learning, USA.

[4] De Marco, S., Holden, D.C., Pardo, L.R., dan McManus, K., 1998, Application of Moisture Barriers for Expansive Soils, Papers, Pardoengineering, L.R.Pardo \& Ass. (Online), ,http://pardoengineering.com.au/ papers/2Japan1998.PDF, last access Sep.1, 2014).

[5] Dye, H.Beata, 2008, Moisture Movement through Expansive Soil and Impact on Performance of Residential Structures, Dissertation, Arizona State University.

[6] Fredlund, D.G. dan Rahardjo, H., 1993, Soil Mechanics for Unsaturated Soils, John Wiley \& Sons Inc., Canada.

[7] Gourley, C.S., Newill, D., dan Schreiner, H.D., 1993, Expansive soils: TRL's research strategy, $1^{\text {st }}$ International Symposium on Engineering Characteristics of Arid Soils, City University, London.

[8] Gullu, H., 2013, Numerical Study on Geotextile Stabilized Highway Embankment under Vibration Loading, 2nd International Balkans Conference on Challenges of Civil Engineering, BCCCE, 23 - 25 May 2013, Albania.

[9] Jones, D.E, dan Holtz, W.G., 1973, Expansive Soils - the Hidden Disaster, Civil Engineering, ASCE Vol.43, November 8, New York.

[10] Nayak, N.V. dan Christensen, R.W., 1971, Swelling Characteristics of Compacted Expansive Soils, Clays and Clay Minerals, Vol 19, Pergamon Press, Printed in Great Britain, (Online), (http://citeseerx.ist.psu.eduviewdocdownloaddoi=10.1.1.519.2619..., last access Dec.12, 2014).

[11] Rogers, J. David, Olshansky, R., dan Rogers, Robert B., 2004, Damage to Foundations from Expansive Soils, hbcconsolidamenti.it., (Online), (http://web.mst.edu/ rogersda/expansive soils/, last access Februari 22, 2015).

[12] Sridharan, A., Prakash, K., 2000, Classification Procedures for Expansive Soils, Proceeding Institution of Civil Engineers, London.

[13] Fathurrahmi, 2013, Identification of Natural Clay's Type Using XRay Diffraction, Jurnal Natural, XXI No. XXI, E-Journal Unsyiah, (Online), (http://www.rp2u.unsyiah.ac.id/index.php/welcome/prosesDownload/1 302/4, last access Dec.26,2015) 